\title{
КОММЕРЧЕСКИЙ ПОДКУП: ПРОБЛЕМЫ КРИМИНАЛИЗАЦИИ
}

\begin{abstract}
COMMERCIAL BRIBERY:
PROBLEMS OF CRIMINALIZATION
V. Markov
R. Khasnutdinov
Summary. The Adoption by the State Duma of the Russian Federation in 2016 of a draft law initiated by the President of the Russian Federation contributed to significant changes in criminal legislation aimed at fighting corruption in the country. Changes in criminal legislation have changed approaches to law enforcement in cases of commercial bribery. However, modern legal norms do not cover all the variety of problems of law enforcement practice. Commercial bribery is defined by law as the illegal receipt of funds for the illegal achievement of one's goals. In theory and practice, it is always considered as a preliminary action performed by a representative of a commercial structure. Commercial bribery is characterized by signs of bribery and embezzlement of budget funds. In the course of this offense, the normal competitiveness of the business environment and activities is violated. It is established that there is no unified approach to the qualification of commercial bribery. At the same time, only administrative liability is provided for the Commission of commercial bribery on behalf of a legal entity. In addition, there is the problem of qualifying a commercial approach involving extortion. In the process of investigating crimes related to commercial bribery, additional circumstances excluding criminal liability are not always taken into account.
\end{abstract}

Keywords: corruption, commercial bribery, bribery, kickback, kickback.

\author{
Марков Владимир Петрович \\ Д.ю.н., доцент, ФГБОУВО «Самарский \\ государственный экономический университет» \\ sf-vguvt@mail.ru \\ Хаснутдинов Ринат Рафаильевачч \\ К.ю.н., дочент, ФГБОУВО «Самарский \\ государственный экономический университет»
}

Аннотация. Принятие Государственной Думой РФ в 2016 г. законопроекта, инициированного Президентом РФ, способствовало значительному внесению изменений в уголовное законодательство, направленных на борьбу с коррупцией в стране. Изменения в уголовном законодательстве изменили подходы к правоприменительной практике по делам в сфере коммерческого подкупа. Тем не менее, современные правовые нормы не охватывают всего многообразия проблем правоприменительной практики. Коммерческий подкуп законодательством определяется как незаконное получение денежных средств для незаконного достижения своих целей. В теории и практике он всегда рассматривается как предварительное действие, совершаемое представителем коммерческой структуры. Коммерческий подкуп отличают признаки взяточничества и хищения бюджетных средств. В процессе данного правонарушения происходит посягательство на нормальную конкурентоспособность предпринимательской среды и деятельности. Установлено, что единого подхода к квалификации коммерческого подкупа не сложилось. При этом за совершение коммерческого подкупа от имени юридического лица предусматривается только привлечение к административной ответственности. Кроме того, существует проблема квалификации коммерческого подхода, сопряженного с вымогательством. В процессе расследования преступлений, связанных с коммерческим подкупом, не всегда учитываются дополнительные обстоятельства, исключающие уголовную ответственность.

Ключевые слова: коррупция, коммерческий подкуп, взятка, откат, kickback.

Анализ решений судов, основанных на антикоррупционных нормах уголовного законодательства, показывала, что данная норма долгое время не охватывала всего многообразия проблем правоприменительной практики [5]. В особенности, когда речь шла о действиях юридических лиц в сфере коммерческого подкупа, риск привлечения к административной ответственности которых, в отличие от физических лиц долгое время оставался невысок.

Однако, наблюдаемые с 2016 года изменения в уголовном законодательстве изменили подходы к правоприменительной практике по делам в сфере коммерческого подкупа. В частности, дополнение Уголовного кодекса РФ статьями 204.1 и 204.2 определило особенности уголовной ответственности за посредничество 
Таблица 1. Процессуальные характеристики коммерческого подкупа[10]

\begin{tabular}{|l|l|}
\hline Основание & Коммерческий подкуп \\
\hline Законодательство & Статья 184 и 204 УК РФ \\
\hline Сфера & Коммерческая деятельность предпринимателей \\
\hline Вид нарушения & Коммерческое нарушение \\
\hline Объект правонарушения & $\begin{array}{l}\text { Реализация прав предпринимателей, стабильность коммерческой деятельности, } \\
\text { добросовестная конкуренция }\end{array}$ \\
\hline Субъекты нарушения & Представители коммерческих организаций \\
\hline Время нарушения & Получение денежных средств перед совершением действия \\
\hline Тяжесть нарушения & При передаче денежных средств и благ тяжесть некрупная, а при получении - крупная \\
\hline Наказание за коммерческий подкуп & $\begin{array}{l}\text { При передаче средств предусмотрен штраф в 10-50-кратном размере от подкупа, } \\
\text { лишение свободы до 2 лет, исправительные работы до } 3 \text { лет. } \\
\text { При получении средств предусмотрен штраф в 15-70-кратном объеме от подкупа, } \\
\text { запрет на дальнейшее занятие деятельностью на срок 3 года, лишение свободы до } 3 \text { лет. }\end{array}$ \\
\hline
\end{tabular}

в коммерческом подкупе и ответственности мелкий коммерческий подкуп. С 2018 года появилась норма, изложенная в статье 304 УК РФ, содержание которой определяет особенности уголовной ответственности за провокацию коммерческого подкупа.

Анализ материалов судебной практики $[3,6]$ и материалов отдельных публикаций $[7,8]$ показывает, что, несмотря на противоправный характер коммерческого подкупа («отката»), единого подхода к его квалификации не существует. Так, например, с точки зрения правоохранителей, коммерческий подкуп в классической схеме попадает под действие сразу нескольких составов преступлений, а именно: статья 285 УК РФ «злоупотребление должностными полномочиями», статья 290 УК РФ «получение взятки» и непосредственно статья 204 УК РФ «получение взятки». Каждый из перечисленных составов посягает на порядок нормального функционирования коммерческой структуры, а также охраняемые законом интересы и права граждан и иных организаций. Кроме того, в отдельных исследованиях [1] подчеркивается двойственность правовой природы отката, что выражается в том факте, что коммерческий подкуп отличают признаки взяточничества и хищения бюджетных средств. Откат (или коммерческий подкуп) как криминальное явление имеет принципиальные отличия его от взятки, что выражается в следующих его признаках: 1) при коммерческом подкупе нередко фигурируют бюджетные денежные средства для исполнения государственного или муниципального контракта; 2) при коммерческом подкупе чиновника все операции происходят от имени юридических лиц; 3) в процессе коммерческого подкупа фигурируют суммы от нескольких сотен до нескольких миллионов рублей.

Специфическим моментом расследования и квалификации коммерческого подкупа является тот факт, что совершение коммерческого подкупа от имени юридического лица предусматривает только привлечение к административной ответственности. Так, статьей 19.28 КоАП РФ предусматривается наложение штрафа в раз- мере трехкратной суммы коммерческого подкупа со стороны юридического лица, которая должна составлять не менее одного миллиона рублей с конфискацией передаваемых денежных средств или иного имущества, имеющего ценность. Вместе с тем, привлечению юридического к административной ответственности сопутствует его привлечение к уголовной ответственности (например, по статье 291 УК РФ «дача взятки») [4; 9].

В уголовном законодательстве коммерческий подкуп определяется как незаконное получение денежных средств для незаконного достижения своих целей. Строго определенный законодательством перечень форм коммерческого подкупа не составляют предметы, которые не поддаются оценке в денежной форме. Также коммерческий подкуп в теории и практике всегда рассматривается как предварительное действие. Обычно он совершается представителем коммерческой структуры. В процессе данного коммерческого правонарушения происходит посягательство на нормальную конкурентоспособность предпринимательской среды и деятельности.

Наглядно сущность проведенных изменений отражена в Таблице 1, где приведены размеры штрафов и степени уголовной ответственности за коммерческий подкуп.

Таким образом, за совершение коммерческого подкупа (отката) предусмотрена уголовная ответственность. Действия по коммерческому подкупу могут быть доказаны на основании показаний свидетелей, материалов розыскных мероприятий, бухгалтерских документов, выписок банковских счетов организаций и иных документов.

Важно подчеркнуть, что в современных условиях существует проблема квалификации коммерческого подхода, сопряженного с вымогательством отката. На этот факт обращает особое внимание в своей публикации Р.О.Долотов [2]. Именно установленный факт вымогательства позволит принять решение об освобождении 
лица осуществившего коммерческий подкуп. Если вымогательство причинило вред интересам коммерческой или иной организации, то нормы, изложенные в статье 23 «Уголовно-процессуального кодекса Российской Федерации» от 18.12.2001 № 174-Ф3 (ред. от 02.08.2019) устанавливают, уголовное дело можно возбудить по заявлению руководителя. И, если вред от коммерческого подкупа нанесен интересам государства, общества, гражданам, то уголовное дело возбуждается без заявления. Следует подчеркнуть, что частое допускаются ошибки квалификации дел о коммерческом подкупе, и связаны они с установлением факта вымогательства.
Таким образом, изменения в уголовном законодательстве повлияли на квалификацию и размер наказания. Вместе с тем, смягчение уголовной ответственности не отвечает основным положениям государственной антикоррупционной политики. Этот вывод подтверждают условия освобождения от уголовной ответственности за коммерческий подкуп, изложенные в статьях 204, 204.1 и 204.2 УК РФ. Такое позитивное посткриминальное поведение субъекта преступления законодателем приветствуется. Небольшие размеры коммерческого подкупа не предусматривают уголовного преследования.

\section{ЛИТЕРАТУРА}

1. Баркатунов В.Ф., Воробьёва Е. А. Тарифное регулирование цен, откаты и система иных коррупционных рисков в экономике современной России / В. Ф. Баркатунов, Е. А. Воробьева // «Политика, экономика и инновации».—2017.— № 1.—C. 1-23.

2. Долотов Р. О. Вымогательство «отката» в коммерческой организации: проблемы квалификации / Р. 0. Долотов // «Уголовное право».— 2017.— № 5. C. $43-39$

3. Домашенко Н. А. Особенности расследования провокации взятки или коммерческого подкупа: автореферат дис. ... кандидата юридических наук. / Н. А. Домашенко — Ростов-на-Дону, 2011. 30 c.

4. «Кодекс Российской Федерации об административных правонарушениях» от 30.12.2001 N195-Ф3 (ред. от 02.08.2019) // СПС Консультант.— [Электронный ресурс].—Режим доступа: http://www.consultant.ru/ (дата обращения: 9.10.2019).

5. Коммерческий подкуп — судебная практика // Правовой портал «Судебные и нормативные акты РФ».— [Электронный ресурс].— Режим доступа: https://sudact.ru/practice/kommercheskij-podkup/ (дата обращения: 9.10.2019).

6. Макашов В. Экономика откатов. Ч. 2 / Тэ «Экономика, политика, власть.— [Электронный ресурс].— Режим доступа: https://blog-v-makashov.livejournal. com/tag/ЭКОНОМИКА\%20ПОЛИТИКА\%20ВЛАСТЬ (дата обращения: 9.10.2019).

7. Рыков А. А. Коммерческий подкуп: понятие, содержание и некоторые проблемы расследования / А. А. Рыков // «Юрист-Правоведъ».— 2010.— № 6. C. 32-35.

8. Сотов А. И., Телегина Т. Д. Правовая природа «отката» / А. И. Сотов, Т. Д. Телегина // «Корпоративный юрист».— 2010.— № 3.—C. 48-52.

9. Суворова А.А., Ермоленко А. А. Представительские расходы: гражданские, административные и уголовные риски / А. А. Суворова, А. А. Ермоленко // Auditit.ru.— [Электронный ресурс].— Режим доступа: https://www.audit-it.ru/articles/account/expenditure/a28/892119.html (дата 0бращения: 9.10.2019).

10. Чем отличается взятка от коммерческого подкупа? / Ассистентус для малого бизнеса.— [Электронный ресурс].— Peжим доступа: https://assistentus.ru/ vedenie-biznesa/chem-otlichaetsya-vzyatka-ot-kommercheskogo-podkupa/ (дата обращения: 9.10.2019). 